Volume 8

Number 2 Student Articles Edition

Article 4

2-16-2022

\title{
Code Harassment Needs a Texas-Sized Solution
}

David Seth Morrison

Texas A \& M University - College Station, dmorriso@tamu.edu

Follow this and additional works at: https://scholarship.law.tamu.edu/journal-of-property-law

Part of the Administrative Law Commons, Law and Society Commons, and the Property Law and Real Estate Commons

\section{Recommended Citation}

David S. Morrison, Code Harassment Needs a Texas-Sized Solution, 8 Tex. A\&M J. Prop. L. 141 (2022). Available at: https://doi.org/10.37419/JPL.V8.I2.4

This Notes \& Comments is brought to you for free and open access by Texas A\&M Law Scholarship. It has been accepted for inclusion in Texas A\&M Journal of Property Law by an authorized editor of Texas A\&M Law Scholarship. For more information, please contact aretteen@law.tamu.edu. 


\title{
Code Harassment Needs a TeXas-Sized Solution
}

\author{
David Seth Morrison ${ }^{\dagger}$
}

\section{Abstract}

Municipal Code Enforcement exists to abate nuisances and resolve conflicts between neighbors. Code enforcement often discovers nuisances through citizen complaints. Cities and code enforcement departments have taken great lengths to protect complainants from retaliation, but these protections have extended too far and created a problem in reverse. Code harassment occurs when people make excessive or false reports to code enforcement departments to harass neighbors. Code enforcement officers do their jobs and investigate the complaints leading to visits and fines. Many people are shocked to find they can do nothing to stop the harassment save leaving their residence because the law offers no protection against such behavior. With a focus on Texas, this Comment looks at the three causes that enable code harassment, places them within the larger framework of code compliance reform that has occurred in the past twenty years, and offers a framework for creating solutions, including reforming the Texas Citizens Participation Act, establishing confidential code enforcement reporting, and creating a vexatious reporter law.

I. INTRODUCTION. 142

II. MUNICIPAL CODE ENFORCEMENT ………............................ 146

A. General Overview .................................................... 146

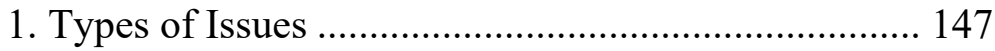

DOI: https://doi.org/10.37419/JPL.V8.I2.4

$\dagger$ J.D. Candidate, Texas A\&M University School of Law, Spring 2022. I would like to thank Professor Angela Morrison for serving as my faculty advisor; this Comment would be a skeleton of its current form without her advice and feedback. I would also like to thank Ryan Cairns, my Note and Comment Editor, for reading through eight drafts of this Comment and providing his insight. Finally, I would like to thank Jonathan D. Berry for helping me to discover the topic of code harassment. I worked with him on a code harassment case during my internship with his firm, and our many frustrations spawned my interest in further researching the topic and finding a potential solution. 
2. Identifying Code Violations ........................................ 147

3. Gaining Compliance .................................................. 149

B. Texas Perspective ……................................................ 149

III. Modern CODE ENFORCEMENT PROBLEMS ............................... 152

A. Abatement ........................................................... 152

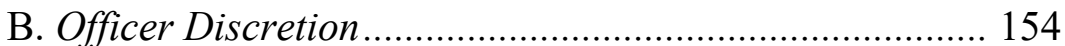

C. Neighborhood Discord ................................................. 158

IV. CODE HARASSMENT: AN UNADDRESSED ISSUE .......................... 161

A. The Texas Citizens Participation Act ............................... 161

B. Anonymous Reporting …………………………............. 162

C. Molding Causes of Action ................................................ 165

1. Criminal Law …………………………………….... 165

2. Tort Law ………………………………………..... 167

V. CREATING A SOLUTION ........................................................ 170

A. Rolling Back the Texas Citizens Participation Act .......... 170

B. Transitioning Anonymous Reporting to Confidential Reporting...

C. Creating a Vexatious Reporting Law ............................... 174

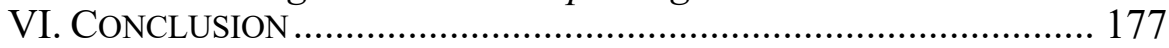

\section{INTRODUCTION}

In 2016, a resident of San Antonio's Beacon Hill neighborhood created a "fearful environment." As neighbors repaired their driveways, the resident would stand in front of the neighbor's properties with a tape measure to ensure the repairs conformed to the city code. ${ }^{2}$ A man bought a building he had lived in as a tenant for years, only to discover that the resident was reporting him to the city for such offenses as parking his car in front of his building. ${ }^{3}$ An elderly woman, who had lived in the neighborhood for 50 years, felt forced to leave "because she felt that [she had] been driven out of the neighborhood." 4 The issue became so pervasive that the neighborhood association, code compliance department, and city council revised the Neighborhood Conservation District plan in 2017 to alleviate the resident's behavior. $^{5}$

1. Gilbert Garcia, Beacon Hill Businesses Cry Code-Compliance Harassment, SAN ANTONIO EXPRESS-NEwS (Oct. 22, 2016), https:/www.expressnews.com/news /news_columnists/gilbert_garcia/article/Beacon-Hill-businesses-cry-code-compliance-10124431.php [https://perma.cc/DEW9-U4YV].

2. $I d$.

3. $I d$.

4. $I d$.

5. Id.; Beacon Hill Area Neighborhood Conservation District, 
The resident's actions against neighbors are an example of what this Comment calls "code harassment." makes an overwhelming number of reports to local municipal code enforcement agencies against another person. ${ }^{7}$ Code enforcement officers, in attempting to perform their jobs, become tools in neighborhood disputes. ${ }^{8}$ Sometimes, officers recognize that they are "becoming involved in what they define as private disputes." 9 Other times, officers may find it difficult to separate the harassment from genuine complaints; consider an incident in Florida where an officer issued a warning "for feeding ducks in [her] back yard instead of on the water, as city codes prescribe." 10

The effects of code harassment are far reaching. First, code harassment wastes city resources as overburdened code compliance departments investigate large volumes of harassing complaints. ${ }^{11}$ Second, citizens suffer as code compliance officers send letters, knock on their doors, enter and search their property, issue fines, and take legal actions against them. ${ }^{12}$ Oftentimes, this causes people to forfeit their

BeAcon Hill ARea NCD Plan 2017 Revisions, at 2 (June 22, 2017), https:/ /www.sanantonio.gov/Portals/0/Files/Planning/NPUD/NCD5_BeaconHill.pdf [https://perma.cc/S3XE-Z5VW].

6. See Bob LaMendola, Vengeful Neighbors Trigger 'Code Terrorism,' S. Fla. Sun SENTINEL (Apr. 30, 1989), https://www.sun-sentinel.com/news/fl-xpm-198904-30-8901220735-story.html [https://perma.cc/CKQ9-QYX4].

7. See id.

8. See id.; Gilbert Garcia, Beacon Hill Businesses Cry Code-Compliance Harassment, SAN ANTONIO EXPRESS-NEWS (Oct. 22, 2016), https://www.expressnews.com/news/news_columnists/gilbert_garcia/article/Beacon-Hill-businessescry-code-compliance-10124431.php [https://perma.cc/DEW9-U4YV].

9. H. Laurence Ross, Housing Code Enforcement as Law in Action, 17 L. \& POL'y 133, 143 (1995) [hereinafter Law in Action].

10. See Bob LaMendola, Vengeful Neighbors Trigger 'Code Terrorism,' S. FLA. Sun SENTINEL (Apr. 30, 1989), https://www.sun-sentinel.com/news/fl-xpm-198904-30-8901220735-story.html [https://perma.cc/CKQ9-QYX4].

11. See generally H. Laurence Ross, Housing Code Enforcement and Urban Decline, 16 J. OF AFFORDABLE Hous. \& CMTY. DEV. L. 29, 39 (1996) [hereinafter Urban Decline] ("The code is very much underenforced due to community and inspection agency resource limitations .... An inspector's luckiest discovery is that an address is outside the city limits."); Marie Saavedra, Mayor Acts as Code Compliance Representative for a Day in West Dallas, WFAA (Feb. 27, 2020), https:/ /www.wfaa.com/article/news/local/dallas-mayor-puts-eyes-on-the-problem-of-neglected-properties/287-509695c2-99e6-4331-94af-f3063305dd34 [https://perma.cc /XA96-UB86] (quoting Dallas Mayor Eric Johnson stating, "I think one of the biggest barriers is just manpower and time. It's a big city and code violations can be many.").

12. See generally Dallas News Administrator, Sounding Off: Is Code Enforced in Your Neighborhood?, THE DALL. MoRNING NeWs (July 21, 2013, 11:00 AM), 
homes and property and leave an area to avoid further harassment. ${ }^{13}$ Finally, judicial resources are wasted as citizens attempt to fight code enforcement and harassing neighbors with inadequate means. ${ }^{14}$

Although code harassment seems confined to neighborhood disputes, the internet has provided a transnational and national platform for code harassers. ${ }^{15}$ In 2016, a concentrated campaign led by anonymous, "self-proclaimed "Right Wing Safety Squads" found on the website 4 chan $^{16}$ closed down local Do-It-Yourself ("DIY") spacesunsanctioned and makeshift locations where "marginalized and transgressive groups"17 gathered to play and hear music - in Toronto, "Baltimore, Denver, Fort Worth, Richmond, Knoxville, [and] Nashville." 18 Group members would locate videos of DIY events online and identify and report fire and building hazards to local authorities. ${ }^{19}$ A 4-chan thread explained the rationale of the "Right Wing Safety Squads" actions, stating, "[DIY Spaces] are open hotbeds of liberal radicalism and degeneracy and now YOU can stop them by reporting all such places you may be or may become aware of to the authorities . . .."20 The rise of the internet and the ease of anonymous communication

https://www.dallasnews.com/news/2013/07/21/sounding-off-is-code-enforced-inyour-neighborhood/ [https://perma.cc/UBV4-7VD6] ("No matter what is done, nobody will be happy, so get used to it."); Bob LaMendola, Vengeful Neighbors Trigger ‘Code Terrorism, 'S. FLA. Sun SENTINEL (Apr. 30, 1989), https://www.sun-sentinel.com/news/fl-xpm-1989-04-30-8901220735-story.html [https://perma.cc /CKQ9-QYX4] ("I live on Social Security. I'm so sick I don't care if they put me in jail. Who would do something like that?").

13. See generally Gilbert Garcia, Beacon Hill Businesses Cry Code-Compliance Harassment, SAN ANTONIO EXPRESS-NEws (Oct. 22, 2016), https://www.expressnews.com/news/news_columnists/gilbert_garcia/article/Beacon-Hill-businessescry-code-compliance-10124431.php [https://perma.cc/DEW9-U4YV]; Robert F. Blomquist, Extreme American Neighborhood Law, 45 GonZ. L. REV. 335, 407 (2009) (citing Clanton v. Carr, No. A104203, 2004 WL 2988609, at *1 (Cal. Ct. App. Dec. 28, 2004)) (illustrating where general harassment from a neighbor forced a family to relocate after three years).

14. See generally in re Lipsky, 411 S.W.3d 530, 536-37 (Tex App.-Fort Worth 2013, pet. denied) (suing for defamation, business disparagement, and civil conspiracy).

15. See Sara Gwendolyn Ross, Transgressive DIY ("Do-It-Yourself") Spaces, Mixed Virtual/Physical Affinity Spaces, and Building Code Vigilantism, 13 ALB. GOV'T. L. REV. 233, 262 (2019) [hereinafter DIY].

16. Id. at 261.

17. Id. at 275 .

18. Id. at 259-61.

19. Id. at 262.

20. Id. at 263 . 
have allowed code harassment to expand from a limited neighborhood scope into a potential tool for silencing political opponents. ${ }^{21}$

Within the past two decades, legal scholars and activists have criticized and called for reform of code enforcement policy. ${ }^{22}$ Code enforcement departments have implemented many of these reforms, however, the conversation has excluded code harassment and its causes. $^{23}$

This Comment seeks to incorporate code harassment into the literature surrounding code enforcement because current code enforcement reform efforts have fallen short. Accordingly, the Comment proposes solutions that lawmakers and code enforcement agencies should adopt in the future. Code enforcement is not uniform across the United States, ${ }^{24}$ so this Comment focuses on Texas as an illustrative case study of the problem and proposes potential solutions in the hopes that other states and cities can modify and enact similar measures.

Four sections comprise this Comment. Section II provides a general overview of code enforcement agencies and a description of code enforcement in various Texas cities. Section III sets out the three problems - abatement, officer discretion, and neighborhood discord - that scholars and organizations have identified over the past two decades with code enforcement and explains their connection to code harassment. Section IV analyzes the three components that enable code harassment in Texas: the Texas Citizens Participation Act, anonymous reporting, and the lack of a clear cause of action. Finally, Section V proposes three solutions that would address code harassment: amending the Texas Citizens Participation Act, transitioning from anonymous reporting to confidential reporting, and creating a vexatious reporter law which would allow people to directly address code harassment in court. Addressing code harassment is important because

21. See id. at 262; Jonathan Simmons, What to Do When Code Enforcement Becomes a Weapon?, PALM COAST OBSERVER (July 8, 2015), https://www.palmcoastobserver.com/article/what-do-when-code-enforcement-becomes-weapon [https://perma.cc/2QH8-XZK6].

22. See generally Marilyn L. Uzdavines, Barking Dogs: Code Enforcement is All Bark and No Bite (Unless the Inspectors Have Assault Rifles), 54 WASHBURN L.J. 161 (2014); Urban Decline, supra note 11; Jonathan Simmons, What to Do When Code Enforcement Becomes a Weapon?, PALM COAST ObSERVER (July 8, 2015), https://www.palmcoastobserver.com/article/what-do-when-code-enforcement-becomes-weapon [https://perma.cc/2QH8-XZK6].

23. See generally Uzdavines, supra note 22; Urban Decline, supra note 11.

24. See Uzdavines, supra note 22, at 168. 
it will offer relief to victims ${ }^{25}$ and prevent code harassment from enlarging into a tool that individuals and groups use to accomplish invidious objectives, such as silencing political opponents ${ }^{26}$ or segregating communities. ${ }^{27}$

\section{MUNICIPAL CODE ENFORCEMENT}

Texas provides an excellent definition of Code Enforcement as the inspection of public or private premises for the purpose of identifying environmental hazards, including: fire or health hazards; nuisance violations; unsafe building conditions; and violations of any fire, health, or building regulation, statute, or ordinance; and improving and rehabilitating those premises with regard to those hazards. ${ }^{28}$

This Section explains how code enforcement agencies generally accomplish this goal before comparing code enforcement in the Texas cities of Fort Worth, San Antonio, and Lubbock.

\section{A. General Overview}

Code enforcement is an issue that cuts right to the heart of everyday life and impacts everybody within a community. In Dallas, Texas, for instance, Mayor Eric Johnson spent an entire day as a code compliance officer to see how the department resolved the 300,000 complaints it receives each year. ${ }^{29}$ During his stint as an officer, Johnson saw a vacant lot filled with "trash, tires, and a broken fence" and stated that this was "certainly one of the things you hear about the most because it gets right to people's quality of life."30 Johnson's focus on various forms of trash illustrates the primary purpose of code

25. Gilbert Garcia, Beacon Hill Businesses Cry Code-Compliance Harassment, SAN ANTONIO EXPRESS-NEWS (Oct. 22, 2016), https://www.expressnews.com/news /news_columnists/gilbert_garcia/article/Beacon-Hill-businesses-cry-code-compliance-10124431.php [https://perma.cc/DEW9-U4YV].

26. See DIY, supra note 15 , at 260-62.

27. See Francisco Alvarado, Lake Worth Uses Cops, Code Enforcement in Brazen Effort to Get Rid of City's Poor, Fla. Bulldog (Mar. 5, 2019), https:/ /www.floridabulldog.org/2019/03/lake-worth-uses-cops-code-enforcement-in-brazen-effort-to-get-rid-of-citys-poor/ [https://perma.cc/RPE8-5TAP].

28. TEX. OCC. CODE $\S 1952.001(1)$.

29. Marie Saavedra, Mayor Acts as Code Compliance Representative for a Day in West Dallas, WFAA (Feb. 27, 2020), https://www.wfaa.com/article/news/local /dallas-mayor-puts-eyes-on-the-problem-of-neglected-properties/287-509695c2-

99e6-4331-94af-f3063305dd34 [https://perma.cc/XA96-UB86].

30. $I d$. 
enforcement: to resolve nuisances and get people to comply with the law, whether by choice or through various forms of force ${ }^{31}$ Code cases that end up out of an officer's hand, in court for instance, are viewed as failures because compliance was not reached. ${ }^{32}$

\section{Types of Issues}

Code enforcement officers confront both internal and external issues. ${ }^{33}$ Internal issues are those that people, mostly tenants, complain about within their own dwellings, "for example, lack of adequate heat." 34 Such issues fall under the purview of the warranty of habitability and exist to hold landlords accountable for the state of properties. ${ }^{35}$ External issues are those that people complain about outside their own dwellings or about other people, such as trash or tall grass. ${ }^{36}$ Such issues fall under the purview of nuisance law and are designed to uphold health and safety within the community. ${ }^{37}$

\section{Identifying Code Violations}

Most code enforcement agencies in the United States operate as complaint-driven systems. ${ }^{38}$ A complaint-driven system relies heavily on community involvement to selectively enforce city ordinances where needed rather than proactively searching for violations. ${ }^{39}$ Code enforcement officers respond to individual complaints so that each neighborhood can determine what it will tolerate for itself. ${ }^{40}$ For example, if a person lives "in an area where it's OK for a trailer" to be in the front yard, then nobody will complain. ${ }^{41}$ Such systems encourage the community to police itself and allow code enforcement to

31. Law in Action, supra note 9, at 149; JULIUS ZSAKO, CODE ENFORCEMENT Best Practices: Safety, Customer Service \& Communications 6 (2018).

32. Law in Action, supra note 9, at 153.

33. Id. at 140 .

34. Id.

35. Ezra Rosser, Rural Housing and Code Enforcement: Navigating Between Values and Housing Types, 13 GeO. J. ON POVERTY L. \& POL'Y. 33, 40 (2006).

36. Law in Action, supra note 9, at 140.

37. See id. at 134; ZSAKO, supra note 31 , at 10.

38. Uzdavines, supra note 22, at 163-64.

39. Id.

40. Betsy Calvert, Code Enforcement Starts With Neighbors, Ends With Government, Sun PORT ChARLOTTE (Apr. 12, 2019), https://www.yoursun.com/charlotte /news/code-enforcement-starts-with-neighbors-ends-with-government/article 217c3096-4a70-11e9-96ba-ab64eac85ce6.html [https://perma.cc/CGB3-XDNF]. 41. $I d$. 
adopt a hands-off approach. ${ }^{42}$ As one Dallas resident stated, code enforcement officers cannot magically know a problem exists unless citizens "help the city help us." 43

A minority of code enforcement agencies adopt proactive systems. ${ }^{44}$ One such method is the use of periodic inspections where inspectors designate a time period to go block by block through an area looking for violations. ${ }^{45}$ Periodic inspections, however, are time consuming, expensive, and often impossible to accomplish with the limited personnel code enforcement agencies have at their disposal. ${ }^{46}$

Another method is geographic inspections, where inspectors focus on the areas that often have the most violations. ${ }^{47}$ This method addresses "the neediest areas" of the community and can compensate for a lack of reporting but fails to address needs in other parts of the community. ${ }^{48}$

Complaint-driven systems often must adopt some elements of proactive enforcement to avoid discrimination claims. ${ }^{49}$ A code enforcement officer will, for instance, respond to a complaint and, after inspecting the reported property, survey the area for similar violations before leaving to avoid charges of discrimination or favoritism. ${ }^{50}$ Such accompanying practices can often cause friction between officers and community members who feel as though officers patrol the streets looking for any excuse to harass them. ${ }^{51}$

42. See id.

43. Dallas News Administrator, Sounding Off: Is Code Enforced in Your Neighborhood?, THE DALL. MoRnING NEws (July 21, 2013, 11:00 AM), https://www.dallasnews.com/news/2013/07/21/sounding-off-is-code-enforced-in-your-neighborhood/ [https://perma.cc/UBV4-7VD6].

44. Uzdavines, supra note 22, at 163.

45. $I d$.

46. $I d$.

47. $I d$.

48. $I d$.

49. Bob LaMendola, Vengeful Neighbors Trigger 'Code Terrorism,' S. FLA. SuN SENTINEL (Apr. 30, 1989), https://www.sun-sentinel.com/news/fl-xpm-1989-04-30 -8901220735-story.html [https://perma.cc/CKQ9-QYX4].

50. See Betsy Calvert, Code enforcement starts with neighbors, ends with government, SUN PORT CHARLOTTE (Apr. 12, 2019), https://www.yoursun.com/charlotte/news/code-enforcement-starts-with-neighbors-ends-with-government/article _217c3096-4a70-11e9-96ba-ab64eac85ce6.html [https://perma.cc/CGB3-XDNF].

51. See Uzdavines, supra note 22, at 163-64. 


\section{Gaining Compliance}

After discovering a violation, a code enforcement officer first issues a notice of violation to the noncomplier. ${ }^{52}$ A notice of violation is a single letter or series of letters sent to a noncomplier and includes the noncomplier's name, "a brief description of the code violation," "a request to eliminate the code violation by a date certain," and "a brief quote from the code which describes the violation ... [and] penalties for non-compliance." 53

After sending out the notice of violation, code enforcement officers will generally default to negotiating with the noncomplier. ${ }^{54}$ Justifying this default approach, one code compliance officer stated, "I don't have anyone in court. If they get to court they stop working on the building. I want to work with them." 55 The approach also comes from a belief that community outreach creates "a positive atmosphere [leading] to safer and more attractive communities, thereby helping to foster better places in which to live, work, play and invest."56

When negotiation fails, violators can end up in court before a judge who assesses a fine for the violation. ${ }^{57}$ Some code enforcement departments have the authority to fix nuisances themselves and charge the costs to the noncomplier using a lien on the property. ${ }^{58}$

\section{B. Texas Perspective}

Code enforcement in Texas is a regulated occupation. ${ }^{59}$ Code enforcement officers in Texas are licensed and registered and must undergo continuing training and education. ${ }^{60}$ Code enforcement officers

52. InT'L Code Council, Legal Aspects of Code Administration 42-43 (2017).

53. ZsAKO, supra note 31, at 47; See also INT'L CoDE COUNCIL, supra note 52, at $42-45$.

54. Urban Decline, supra note 11 , at 36-37

55. Id. at 37.

56. ZsAKO, supra note 31 , at 6-7.

57. Law in Action, supra note 9, at 153-54; Uzdavines, supra note 22, at 171.

58. See Fort Worth, TeX., CODE OF ORdinAnCES app. B, art. II, $\S \S 11 \mathrm{~A}-52$ to $-54(2021)$.

59. TEX. OCC. CODE $§ 1952.001$.

60. Id. $\S 1952.051$ (a)-(b) (an executive director and commission is required to enforce and create standards and educational requirements); Id. $\S \S 1952.102-.103$ (setting out licensing requirements to become a code enforcement officer); Id. $\S$ 1952.1051 (requiring continuing education and training for code enforcement officials); Id. $\S 1952.151$ (stating conditions for suspending or revoking a code enforcement official's license). 
are distinctly different from police officers, despite conducting investigations, imposing fines on people for infractions, and often working in the same building. ${ }^{61}$

Despite state regulation of code enforcement licensing, code enforcement officers operate differently from city to city based on the city ordinance code. ${ }^{62}$ In Fort Worth, for instance, code enforcement operates as its own independent department. ${ }^{63}$ The department operates on a complaint-driven system, ${ }^{64}$ but checking on the status of a complaint requires a complainant to submit their identity with the complaint. ${ }^{65}$ The "Fort Worth Code Rangers," a volunteer system where code enforcement officers train concerned citizens in the community to report violations, supplements Fort Worth's complaint driven system. ${ }^{66}$ After discovering a violation and issuing a notice of violation, officers may abate the nuisances themselves, provide subsequent notice of the abatement to owners, and place liens on property to cover the abatement expenses. ${ }^{67}$

In San Antonio, code enforcement operates as its own independent department. ${ }^{68}$ The department operates on a complaint-driven

61. See Code Enforcement, CITY OF EL PASO, https://www.elpasotexas.gov/police-department/code-compliance [https://perma.cc/L2BX-95DT]; TEX. CRIM. PROC. CODE $\S 2.12$ (Texas law recognizes thirty-five different positions as police officers and none include code enforcement officers); TEX. OCC. CODE $\S 1952.003$ ("This state or a political subdivision of this state may engage in code enforcement without employing a person registered under this chapter.”); Experience Requirements, TEX. DEP'T OF LICENSING \& REGUL., https://www.tdlr.texas.gov/ceo /ceofaq.htm [https://perma.cc/G63Z-7E5D] (a police officer must make a "career change" to be a code enforcement officer).

62. See generally, FORT WORTH, TEX., CODE OF ORdinANCES app. B, art. II, $\S \S$ 11A-6 to -101 (2020); SAn Antonio, Tex., Property Maintenance Code ch. 1, $\S \S 101.1-604.3$ (2020).

63. Fort Worth, Tex., Code of Ordinances app. B, art. II, § 11A-6 (2020).

64. Request a City Service, FORT WORTH, https://fortworth-csrprodcwi.motorolasolutions.com/servicerequest.mvc/srintake [https://perma.cc/LFJ3$8 \mathrm{AAX}]$.

65. Check Service Request Status, FORT WORTH, https://fortworth-csrprodcwi.motorolasolutions.com/StatusCheck.mvc/StatusCheck [https://perma.cc/A65FEYV5].

66. Code Rangers, FORT WORTH, http://cctfortworth.org/coderangers /\#: : text $=$ The $\% 20$ Code $\% 20$ Rangers $\% 20$ program $\% 20$ seeks,reports $\% 20$ of $\% 20$ suspected $\% 20$ code $\% 20$ violations [https://perma.cc/RRL3-5UWT].

67. Fort Worth, TeX., CODE OF ORdinANCES app. B, art. II, $\S \S 11 \mathrm{~A}-52$ to -54 (2020).

68. San Antonio, Tex., Property Maintenance Code, ch. 1, $\S \S 101.1-104.6$ (2018) (established through the San Antonio Property Maintenance Code, also called the Development Services Department). 
system, but does not foreclose proactive inspection. ${ }^{69}$ After discovering a violation, officers must serve a notice of violation on the violator, bring the violator into court if the violation is not fixed, and impose a fine "not less than one hundred dollars and not more than two thousand dollars."70 The code does "not preclude the City Attorney from instituting appropriate action to restrain, correct or abate a violation.",71

In Lubbock, code enforcement operates as a subdivision of the city's environmental inspection services. ${ }^{72}$ The city reporting system is not anonymous because it requires calling or signing into an online account in order to submit a complaint. ${ }^{73}$ At times, the code enforcement department goes out into the community looking for violations. ${ }^{74}$ After discovering a violation, officers may abate the nuisances within one year of notice, provide subsequent notice to owners of the abatement, and charge the owner for abatement. ${ }^{75}$

Enforcement systems and the anonymity of reporting systems separate the three cities above. Both Fort Worth and Lubbock enforce the city code through abating nuisances and charging the property owner, ${ }^{76}$ while San Antonio fines property owners for non-compliance. ${ }^{77}$ Fort Worth depends on a complaint-based system, ${ }^{78}$ while San Antonio and Lubbock use a mixture of proactive and complaint-based

69. Code Enforcement Process, SAn AnTONIO, https://www.sanantonio.gov/ces /Services [https://perma.cc/X5TY-KPFK]. (2018).

70. San Antonio, TeX., Property Maintenance Code ch. 1, §§ 106.1-106.6

71. Id. at $\S 106.5$.

72. LubBOCK, TeX., CODE OF ORDinANCES ch. 34, § 34.02 .031 (2020).

73. Code Enforcement, LUBBOCK, https://ci.lubbock.tx.us/departments/code-enforcement/services [https://perma.cc/WQ4A-PKAV].

74. Avery Travis, Code Enforcement on the Lookout for Violations, KAMC NEws (Apr. 5, 2018), https://www.everythinglubbock.com/news/kamc-news/codeenforcement-on-the-lookout-for-violations/ [https://perma.cc/XUK4-85HY].

75. LuBBOCK, TEX., CODE OF ORDINANCES ch. 34, § 34.02.035 (2020).

76. See Fort Worth, Tex., Code of Ordinances app. B, art. II, $\S \S 11 \mathrm{~A}-52$ to -54 (2019); LUBBOCK, TEX., CODE OF ORDINANCES ch. 34, § 34.02.035 (2020).

77. See San Antonio, Tex., Property Maintenance Code ch. $1, \S 106.4$ (2018).

78. See Request a City Service, FORT WORTH, https://fortworth-csrprodcwi.motorolasolutions.com/servicerequest.mvc/srintake [https://perma.cc/LFJ38AAX]; Code Rangers, FORT WORTH, http://cctfortworth.org/coderangers /\#: :text $=$ The $\% 20$ Code $\% 20$ Rangers $\% 20$ program $\% 20$ seeks, reports $\% 20$ of $\% 20$ suspected\%20code\%20violations [https://perma.cc/RRL3-5UWT] (requiring registered Fort Worth residents to search for violations and submit complaints to Fort Worth Code Enforcement). 
systems. ${ }^{79}$ Lubbock does not use anonymous complaints, ${ }^{80}$ while both San Antonio and Fort Worth allow the submission of anonymous complaints. ${ }^{81}$

\section{MODERN CODE ENFORCEMENT PROBLEMS}

Scholars have identified three major problems with modern code enforcement: inadequate abatement procedures, officer discretion, and failure to resolve neighborhood disputes. ${ }^{82}$ This Section discusses each of these problems with both proposed and enacted solutions and further explains how these problems inadequately address code harassment.

\section{A. Abatement}

Code enforcement's purpose is compliance. ${ }^{83}$ Scholars have criticized code enforcement mechanisms, such as San Antonio's fine system, as ineffective because they prevent noncompliers from addressing issues. ${ }^{84}$ For example, Professor Marilyn L. Uzdavines provides the example of a homeowner who had to move for foreclosure to avoid jail time for failing to repair her damaged roof. ${ }^{85}$ The homeowner's house was in foreclosure when the roof was damaged, ${ }^{86}$ but code enforcement still cited her, ordered her to make repairs, and threatened to incarcerate her. ${ }^{87}$ The homeowner could not fix her roof because

79. See Code Enforcement Process, SAN ANTONIO, https://www.sanantonio.gov /ces/Services [https://perma.cc/X5TY-KPFK]; Code Enforcement, LUBBOCK, https: //ci.lubbock.tx.us/departments/code-enforcement/services [https://perma.cc/WQ4A -PKAV]; Avery Travis, Code Enforcement on the Lookout for Violations, KAMC NEws (Apr. 5, 2018), https://www.everythinglubbock.com/news/kamc-news/codeenforcement-on-the-lookout-for-violations/ [https://perma.cc/XUK4-85HY].

80. See Code Enforcement, LUBBOCK, https://ci.lubbock.tx.us/departments/code -enforcement/services [https://perma.cc/WQ4A-PKAV]; Sign in, SEECLICKFIX, https://seeclickfix.com/oauth/login [https://perma.cc/4QYX-W8MF] (showing the account creation page before submitting a complaint to Lubbock Code Enforcement Department).

81. See Request a City Service, FORT WORTH, https://fortworth-csrprodcwi.motorolasolutions.com/servicerequest.mvc/srintake [https://perma.cc/LFJ38AAX]; Code Enforcement Process, SAN ANTONIO, https://www.sanantonio.gov /ces/Services [https://perma.cc/X5TY-KPFK].

82. See generally Uzdavines, supra note 22, at 161; Rosser, supra note 35 at 33.

83. ZsAKO, supra note 31 , at 47.

84. Uzdavines, supra note 22, at 190.

85. Id. at $175-76$.

86. Id. at 176 .

87. Id. 
she had no money, insurance refused to pay on a foreclosing house, and lenders refused assistance because she was not the owner. ${ }^{88}$ Sending the woman to jail would not have accomplished code enforcement's objective, fixing the roof. ${ }^{89}$ Rather than taking actions that resolve issues, many code enforcement departments rely on outdated practices that punish citizens and prevent compliance. ${ }^{90}$

In addition, code enforcement officers sometimes avoid acting for fear of harming people in the community. ${ }^{91}$ One code enforcement officer voiced his concern with imposing actions and fines against "poor and elderly owner-occupants" stating:

I can't bother her. She is eighty years old, like my mother.

To fix that would be ten, twelve, thousand dollars. It can't be worth that. It would be better for her to put money in the bank at ten percent and having something to eat. ${ }^{92}$

In such situations, code enforcement officers see potential intervention as a negative course of action that harms, rather than benefits, a community. ${ }^{93}$

In the past two decades, and especially since the 2008 housing crash which lead to a rise of abandoned and decaying homes, ${ }^{94}$ some states have attempted to use super-liens to address inadequate abatement procedures. ${ }^{95}$ Although many Texas cities allow city officials to abate nuisances on their own and file liens, ${ }^{96}$ such liens are treated as normal liens and fall behind any already existing liens on a property. ${ }^{97}$ A super-lien takes priority over other liens. ${ }^{98}$ This allows homeowners, especially those with little money, to pay for abatement, usually property improvements that make life better, before paying other debts

\section{Id.}

89. Id.

90. See San. Antonio, Tex., Property Maintenance Code ch. $1, \S 106.4$ (2018).

91. Urban Decline, supra note 11, at 36; Rosser, supra note 35, at 92.

92. Urban Decline, supra note 11, at 36.

93. See id.

94. Uzdavines, supra note 22, at 184-85.

95. Id. at 181-85 (Louisiana has explicitly authorized super-liens throughout the state allowing it to recover $\$ 3.4$ million. Florida and Massachusetts have attempted to establish super-liens by giving priority to certain liens through select court cases with marginal success.).

96. See Fort Worth, TeX., Code of Ordinances, app. B, art. II, $\S \S 11 \mathrm{~A}-52$ to -54 (2019); LuBBOCK, TEX., CODE OF ORDINANCES ch. 34, § 34.02 .035 (2020).

97. Uzdavines, supra note 22, at 181.

98. Id. 
that may keep a property in disrepair. ${ }^{99}$ Super-liens work better than fines because they use government money to immediately fix and resolve issues, the stated objective of code enforcement, rather than depriving homeowners of money while simultaneously demanding compliance. $^{100}$

Abatement and enforcement mechanisms do not address code harassment. Abatement issues exist in the space between code enforcement officers and property owners and do not include complainants; ${ }^{101}$ a person who makes a report to code enforcement has no control over code enforcement's actions.

Although reducing the punitive nature of abatement procedures can reduce the financial impacts on code harassment victims, ${ }^{102}$ such solutions fail to address code harassment's other consequences. The peace of mind and reputational damage a victim faces through repeated code enforcement encounters is a harm suffered long before abatement procedures take place. ${ }^{103}$ Although important and beneficial, abatement reform is inadequate in addressing code harassment's causes or harms.

\section{B. Officer Discretion}

Another issue is the large amount of discretion cities and departments grant code enforcement officers. ${ }^{104}$ When citizens complain, a small handful of code enforcement officers decide what and how to investigate and the approach used to resolve issues. ${ }^{105}$ An investigation from an overzealous, negligent, or untrained officer can have dire repercussions. ${ }^{106}$

\footnotetext{
99. Id. at 182 .

100. See id.

101. See id. at 175 (showing that abatement issues are between code enforcement officers and non-compliant residents).

102. See id. at 181-85.

103. See generally Dallas News Administrator, Sounding Off: Is Code Enforced in Your Neighborhood?, The Dall. MoRning News (July 21, 2013, 11:00 AM), https://www.dallasnews.com/news/2013/07/21/sounding-off-is-code-enforced-inyour-neighborhood/ [https://perma.cc/UBV4-7VD6]; Bob LaMendola, Vengeful Neighbors Trigger 'Code Terrorism,' S. Fla. Sun SENTINEL (Apr. 30, 1989), https: //www.sun-sentinel.com/news/fl-xpm-1989-04-30-8901220735-story.html [https:/ /perma.cc/CKQ9-QYX4].

104. See generally Law in Action, supra note 9; Uzdavines, supra note 22, at 161.

105. See Law in Action, supra note 9, at 143-44.

106. See, Uzdavines, supra note 22, at 178; ZsAKo, supra note 31, at 47; Urban Decline, supra note 11, at 36-38 ("If it honestly takes 300 days to fix a violation I
} 
For example, in Dallas, an elderly homeowner's family suggested a code enforcement officer's action may have led to the homeowner's death. ${ }^{107} \mathrm{~A}$ code enforcement officer and a police officer entered and inspected a 95-year-old homeowner's home without permission. ${ }^{108}$ Two days later, the code enforcement officer returned with a caseworker and told the homeowner she would no longer be able to live in her home. ${ }^{109}$ The homeowner had never interacted with police or city representatives and suddenly found a police officer, code enforcement officer, and caseworker in her home threatening to evict her. ${ }^{110}$ The homeowner died of a stroke within two weeks of the events, and her son suggested that the code enforcement officer caused the homeowner undue stress leading to her death. ${ }^{111}$ The city fired the officer stating her behavior was inconsistent with the standards of the code enforcement department, but this occurred only after seven prior reprimands. ${ }^{112}$

City officials often dismiss negligent or overzealous incidents as the mistake of one bad apple or use appeals of "common sense" that a problem will not occur. ${ }^{113}$ In a Florida case, for instance, the city attorney told the city council:

If the code enforcement officer receives, for the sake of argument, the 10th complaint on the same property from the same anonymous source in one month, they're going to grab their investigator hat, and they're going to use their common sense - and I see it happen - and if there's not a code violation, that's the end of it. ${ }^{114}$

Sometimes, however, cities themselves pressure code enforcement officers to target vulnerable communities. Such a situation

will give the time," but "if somebody lies to me I will burn them so bad that they sure "nuf won't forget it.").

107. Jimmy Isaac, Longview Could Face Lawsuit Over Code Officer's Behavior, LONGVIEW NEWS-J. (Feb. 22, 2018), https://www.news-journal.com/news/local /longview-could-face-lawsuit-over-code-officers-behavior/article_67ab2ad1-9ea1-

540e-b126-6a33d01c5dff.html [https://perma.cc/RH22-4JLE].

108. Id.

109. Id.

110. Id.

111. Id.

112. $I d$.

113. Jonathan Simmons, What to Do When Code Enforcement Becomes a Weapon?, PALM COAST OBSERVER (July 8, 2015), https://www.palmcoastobserver.com/article/what-do-when-code-enforcement-becomes-weapon [https://perma.cc/2QH8-XZK6]. 114. Id. 
occurred in the city of Lake Worth, Florida, where a city council member stated in a meeting, "We have to change the demographics, but no one is willing to say it ... Lake Worth is the default repository for the poor and indigent." 115 Another council member wanting "to attract individuals making $\$ 60,000$ or more annually, preferably with a college degree" stated, "I want that person. That person probably has a higher level of education than our average resident." 116 The council members further stated that law and code enforcement could function as "the stick' to go after owners of dilapidated properties." 117 Following the statements, the city used "a $\$ 300,000$ federal community block grant to fund a citywide sweep" for violations that primarily targeted lowincome Guatemalan and Haitian residents. ${ }^{118}$ Code enforcement officers used their discretion to target individuals in the community, for example, towing specific cars parked on the street or fining the residents of a trailer park. ${ }^{119}$

The Lake Worth council members' comments followed a decade of discriminatory code enforcement practices against Guatemalan and Haitian residents. In 2006, a Lake Worth police officer entered a Guatemalan apartment to take a crime victim report and simultaneously scanned the residence for code compliance violations to report to the code compliance department, a practice that officers did not perform when taking reports from white residents. ${ }^{120}$ After reporting the incident to code compliance, 100 Guatemalan residents were forcibly evacuated from the entire apartment complex. ${ }^{121}$ Lawyers from the Florida Equal Justice Center and Legal Aid Society of Palm Beach County became involved, and the city settled, but the settlement did

115. Francisco Alvarado, Lake Worth Uses Cops, Code Enforcement in Brazen Effort to Get Rid of City's Poor, FLA. BulldoG (Mar. 5, 2019), https://www.floridabulldog.org/2019/03/lake-worth-uses-cops-code-enforcement-in-brazen-effort-toget-rid-of-citys-poor/ [https://perma.cc/RPE8-5TAP].

116. Id.

117. Id.

118. $I d$.

119. Id.

120. Nancy Kinnally, Goldstein Award Winners Challenged Selective Code Enforcement, THE FLA. BAR (June 1, 2010), https://www.floridabar.org/the-florida-bar -news/goldstein-award-winners-challenged-selective-code-enforcement /?fbclid=IwAR1nivcv7s1Mb_G1uG-VzjIfbOvftQxW7JL8L-KxgXD7XfBEpD _vYY9g5hI [https://perma.cc/7AGA-SZ2E].

121. Id. 
little to prevent the subsequent authorization of discriminatory code enforcement officer conduct. ${ }^{122}$

One solution to negligent, overzealous, and discriminatory officer discretions is the "co-production model," which revolves around the community. ${ }^{123}$ The model uses community organizations that understand the unique needs of their communities, negotiate what standard the community should abide, and take it upon themselves to abate non -compliance, for instance, boarding up abandoned houses and keeping records of suspected drug dealings. ${ }^{124}$ The approach was "successfully implemented by several communities in Baltimore" in the late $1990 \mathrm{~s}^{125}$ and has seen increased adoption in the past two decades in various cities across the United States. ${ }^{126}$ Rather than fining residents through city-wide standards, members of the community negotiate and help one another make the community a better place. ${ }^{127}$ When the community organizations encounter a problem too difficult to handle alone, code enforcement provides support through other enforcement mechanisms. ${ }^{128}$

An important aspect of the co-production model is that it deprives code enforcement departments of their potential for abuse. ${ }^{129}$ Rather than forcing individual officers to make decisions from their viewpoints alone, the model allows the community to help officers "develop the best strategy ... while at the same time building up community morale." 130 The result is that officers get "the extra help and financial resources" they need while "the community gets a code

122. Id.; Francisco Alvarado, Lake Worth Uses Cops, Code Enforcement in Brazen Effort to Get Rid of City's Poor, FlA. Bulldog (Mar. 5, 2019), https:/ /www.floridabulldog.org/2019/03/lake-worth-uses-cops-code-enforcement-in-brazen-effort-to-get-rid-of-citys-poor/ [https://perma.cc/9LBR-HTVM].

123. Uzdavines, supra note 22, at 187.

124. Id. at 188 .

125. Id.

126. See Cities Rise: Cities for Responsible InV. And Strategic EnF'T, The POWER \& PROXIMITY OF CODE ENFORCEMENT: A TOOL FOR EQUiTABle NEIGHBORHOODS 23-25 (June 2019) (describing examples in Minnesota, South Carolina, California, and Kansas); Code Rangers, FORT WORTH, http://cctfortworth.org /coderangers/\#: : :text $=$ The $\% 20$ Code $\% 20$ Rangers $\% 20$ program $\% 20$ seeks,re-

ports $\% 20$ of $\% 20$ suspected\%20code\%20violations [https://perma.cc/RRL3-5UWT].

127. Uzdavines, supra note 22, at 188.

128. Id.

129. Id. at 190.

130. Id. 
enforcement department that is listening to the community needs, and working with the residents and not against them." 131

Officer discretion is an additional component leading to code harassment. Oftentimes, a code enforcement officer can flag meritless complaints and refuse to participate in a harassing complaint. ${ }^{132}$ But code officers make mistakes. ${ }^{133}$ These mistakes can create situations where a person finds themselves frequently investigated for non-compliance. $^{134}$

Further, focusing on code enforcement officers ignores the perpetrator of such behavior, the complainant. Because of this, the co-production model fails to address this aspect of code harassment since it is usually a community member who is creating the harassment. ${ }^{135}$ Although the co-production model mitigates the harms of officer discretion, it only shifts the authority that can continue to enable code harassment.

\section{Neighborhood Discord}

The last code enforcement problem is the legal system's general inability to resolve neighbor disputes. ${ }^{136}$ Oftentimes, code enforcement, law enforcement, and court actions have no effect and even exacerbate conflicts between neighbors. ${ }^{137}$ In Tennessee, for instance, a family submitted an anonymous complaint to local code enforcement against their neighbors. ${ }^{138}$ Code enforcement responded with a notice

131. Id.

132. See Law in Action, supra note 9, at 143-44.

133. See generally Jimmy Isaac, Longview Could Face Lawsuit Over Code Officer's Behavior, LoNGVIEW NEwS-J. (Feb. 22, 2018), https://www.news-journal.com/news/local/longview-could-face-lawsuit-over-code-officers-behavior/article_67ab2ad1-9ea1-540e-b126-6a33d01c5dff.html [https://perma.cc/RH22-4JLE].

1354. See Gilbert Garcia, Beacon Hill Businesses Cry Code-Compliance Harassment, SAN ANTONIO EXPRESS-NEwS (Oct. 22, 2016), https://www.expressnews.com /news/news_columnists/gilbert_garcia/article/Beacon-Hill-businesses-cry-codecompliance-10124431.php [https://perma.cc/DEW9-U4YV]; Bob LaMendola, Vengeful Neighbors Trigger 'Code Terrorism,' S. Fla. Sun SEnTINEL (Apr. 30, 1989), https://www.sun-sentinel.com/news/fl-xpm-1989-04-30-8901220735story.html [https://perma.cc/CKQ9-QYX4].

135. See Gilbert Garcia, Beacon Hill Businesses Cry Code-Compliance Harassment, SAN ANTONIO EXPRESS-NEwS (Oct. 22, 2016), https://www.expressnews.com /news/news_columnists/gilbert_garcia/article/Beacon-Hill-businesses-cry-codecompliance-10124431.php [https://perma.cc/DEW9-U4YV].

136. See generally Blomquist, supra note 13.

137. See generally id. at 336-45.

138. Id. at 400 (citing Levy v. Franks, 159 S.W.3d 66, 70 (Tenn. Ct. App. 2004)). 
of violation to the neighbor. ${ }^{139}$ The neighbor was able to discover that the family submitted the anonymous complaint, beginning a six-year feud complete with death threats, court actions, and harassment. ${ }^{140}$ During this time, city officials had no effect or ignored the conflict, court-ordered mediation exacerbated the feud, and judges admonished both parties equally in court. ${ }^{141}$

Many code enforcement officers recognize their inability to resolve neighbor disputes. ${ }^{142}$ Instead of resolving issues, officers sometimes pretend they do not exist. ${ }^{143}$ Referring to a neighbor who constantly complained, one officer stated, "I know the asshole who made this complaint. She is always complaining on her neighbor, and never for any good reason, so why waste time going there? I know it is nothing." 144

Moreover, when complaining neighbors keep submitting complaints, code enforcement officers may take steps against the reporter to stop the complaints. One officer stated, "When I suspect a vindictive complaint from a neighbor, I go over and write up everything there. You never hear from them again." "Such admissions illustrate that code enforcement officers are often aware they do not possess the tools to resolve neighbor disputes and take steps to avoid acting as intermediaries in the disputes. ${ }^{146}$

Ironically, many neighbors expect and rely on city officials to resolve such issues. ${ }^{147}$ A study in New York City found that one-third of people have never interacted with their neighbors. ${ }^{148}$ Further, the study found that people living in "liminal zones," areas of great racial diversity, were far more likely to contact code enforcement than people living in areas of low diversity. ${ }^{149}$ Code enforcement's inability to resolve disputes was a contributing factor to the unrest of these areas

\footnotetext{
139. Id.

140. Id. at 400-05 (citing Levy, 159 S.W.3d at 70).

141. Id.

142. See generally Law in Action, supra note 9, at 143-44.

143. Id. at 144 .

144. Id.

145. Id.

146. See id. at 143-44.

147. Id. at 137 .

148. Laura Bliss, When Racial Boundaries are Blurry, Neighbors Take Complaints Straight to 311, BloOMBERG CiTYLaB (Aug. 24, 2015, 3:01 PM), https:/ /www.bloomberg.com/news/articles/2015-08-24/neighbors-complain-most-to-311along-fuzzy-racial-boundaries-nyu-study-finds [https://perma.cc/N6DQ-3WCV]. 149. Id.
} 
and increased community tension. ${ }^{150}$ Scholars, therefore, have criticized the abatement model as inadequate for resolving the problems that such nuisances actually present. ${ }^{151}$

Currently, no equitable solution or framework capable of resolving such issues exists. ${ }^{152}$ This has led some scholars to look internationally for solutions, specifically at the United Kingdom's "model of Anti-Social Behavior Orders" ("ASBQs"), which arose from extreme situations where the "outrageous behavior of one or two families, groups or individuals [was] apparently beyond the reach of the law."153 Such laws allow courts to use criminal penalties, "such as restricted movement," "even though [a person] may not be guilty of a criminal offense." 154

Of the three issues scholars have raised concerning problems with municipal code enforcement, code enforcement officer's inability to resolve neighborhood disputes most closely addresses the problem. Code harassment is, at its core, a conflict between individuals with an intermediary in between. Although code harassment would not exist without a code enforcement officer, it is the officer's inability to manage a dispute that creates the problem. ${ }^{155}$

However, the creation of a new law based around anti-social behavior would do little to provide relief to code harassment victims. Such laws could prohibit or stop a neighbor's actions, but the victim of harassment still has suffered harm with no legal remedy. ${ }^{156}$

Accordingly, code harassment is an unaddressed issue. Further, proposed and enacted solutions to other code enforcement problems fail to address code harassment because these solutions do not enable a victim to seek a remedy from the harasser.

150. Id.

151. See Blomquist, supra note 13, at 431-32.

152. See generally id. (detailing dozens of such failures by the American legal system).

153. Id. at 433 .

154. Id.

155. See id. at 400-05 (citing Levy v. Franks, 159 S.W.3d 66, 70 (Tenn. Ct. App. 2004)).

156. See id. at 406 (citing Clanton v. Carr, No. A104203, 2004 WL 2988609, at *2-5 (Cal. Ct. App. Dec. 28, 2004)). 


\section{CODE HARASSMENT: AN UNADDRESSED ISSUE}

A Texas victim of code harassment has no clear and easy path to relief in the State's legal system. This problem is threefold: first, the Texas Citizen's Participation Act ("TCPA") imposes a strict procedural dam for code harassment claims; second, most cities allow anonymous reporting that shields harassers' identities; and third, there is no cause of action that directly addresses code harassment. These three issues prevent causes of action based on code harassment and shield such harassing conduct from liability.

\section{A. The Texas Citizens Participation Act}

The "Texas Citizens Participation Act," or "Anti-Slaap Law," is a procedural dam to code harassment claims. ${ }^{157}$ The law allows a party in a legal proceeding to file a motion to dismiss "if [the] legal action is based on, relates to, or is in response to the party's exercise of the right of free speech [or] right to petition . . .." ${ }^{158}$ Courts have read the definition of "right to petition" and "exercise of the right of free speech" very broadly. ${ }^{159}$ For instance, in In re Lipsky, the Fort Worth Court of Appeals decided plaintiffs' complaints to the EPA, that further appeared in various publications, fell within the TCPA's definition of "right to petition" and "exercise of the right of free speech." 160 The plaintiffs properly exercised their right to petition because "the statements at issue were made to encourage the 'review of an issue' . . by a 'governmental body." "161 The exercise of right of free speech was the basis of the plaintiff's actions because the complaint was "made in connection with a matter of public concern."162

157. Laurel L. Baker, Limitations of the Texas Citizens Participation Act, LAW.COM (Jan. 5, 2021, 03:00 PM), https://www.law.com/texaslawyer/2021/01/05 /limitations-of-the-texas-citizens-participation-act/ GQPU].

158. Tex. Civ. Prac. \& REM. Code $§ 27.003($ a) (2011) (amended 2019).

159. See In re Lipsky, 411 S.W.3d 530, 543 (Tex App.-Fort Worth Apr. 22, 2013, pet. denied); Cunningham v. Waymire, 612 S.W.3d 47, 57-59 (Tex. App.Houston [14 ${ }^{\text {th }}$ Dist. $] 2019$, no pet.).

160. 411 S.W.3d at $541-42,545,548$.

161. Id. at 542 (finding the communications to the public at large were "based on [plaintiff's] strategy to involve the EPA").

162. Id. at 542-43 (reasoning that chemicals in the drinking well were a health risk, and fracking could affect others). 
After Lipsky, complainants have used the TCPA to stop defamation or slander suits based on their reports to code enforcement. ${ }^{163} \mathrm{In}$ Maldonado v. Franklin, a court determined that a defendant's complaints to code enforcement about a plaintiff's treatment of an outside dog were "communications made in connection with a matter of public concern." 164 Looking at the San Antonio municipal code, the court determined that San Antonio had made the welfare of an outside dog a matter of public concern and the TCPA protected the defendant's complaints. ${ }^{165}$ Therefore, code enforcement complaints, so long as they conform to nuisances contained within the city ordinance code, are protected speech subject to a TCPA dismissal. ${ }^{166}$

\section{B. Anonymous Reporting}

Anonymous reporting is meant to protect reporters from the people they report, as a case in Salt Lake City, Utah, demonstrates. ${ }^{167}$ In 2018, a man killed a code enforcement officer, lit her truck on fire, and set fire to the neighbor's house he falsely blamed for reporting him. ${ }^{168}$ The man had a history of code enforcement violations for "misdemeanor weed-control and bulky waste-accumulation charges."169 Notably, a week before the murder, the man accused the same neighbor of making the report, but she denied it. ${ }^{170}$

Anonymity exists to allow people to make reports without fear of retaliation, but anonymity also allows code harassers to act free of consequences because the victim of harassment is unable to find out who the harasser is. Most cities in Texas allow anonymous online reporting that collects no personal information from a reporter; in such situations, a request for information from the code compliance department would reveal no information besides the complaint's content. ${ }^{171}$ Thus,

163. See Maldonado v. Franklin, No. 04-18-00819-CV, 2019 Tex. App. LEXIS 8747 (4th Dist. Ct., Bexar County, Tex. Sep. 30, 2019).

164. Id. at *7.

165. Id. at *8 (San Antonio's municipal code "establishe[d] minimum standards of care to safeguard humane care and treatment of animals.").

166. See id.

167. Lindsay Whitehurst, Man Says He Killed City Worker Over Yard Rule 'Harassment,' AsSOCIATED PRESS (Aug. 10, 2018), https://apnews.com/article /bde88b80d72147859f5d6a7a4d621ef2 [https://perma.cc/9CET-46TX].

168. Id.

169. Id.

170. Id.

171. See Check Service Request Status, FORT WORTH, https://fortworth- 
a victim of code harassment seeking to bring an anonymous harasser into court has two options: file an anonymous lawsuit in the hopes of later discovering the identity of the harasser or submit a suit based on a guess as to the who the harasser is and risk dismissal under the TCPA.

Anonymous lawsuits, also known as John/Jane Doe suits, are not accepted in Texas and are dismissed ${ }^{172}$ unless specifically allowed by statute. ${ }^{173}$ In Dallas, for instance, a pro se litigant attempted to bring a defamation claim against an unknown person who reported what he called a "false complaint" to code enforcement. ${ }^{174}$ The litigant later had to amend his complaint to include the neighbor he blamed for the complaint against him. ${ }^{175}$

Alternatively, a plaintiff must sue a defendant and risk TCPA dismissal because the plaintiff cannot prove the defendant made a code enforcement report. Once a defendant invokes the TCPA, plaintiffs must prove "by clear and specific evidence a prima facie case for each essential element of the claim in question," or the court will dismiss the complaint. ${ }^{176}$ The TCPA "does not define what sort of evidence satisfies the 'clear and specific' qualitative standard." 177 In cases unrelated to the TCPA, Texas courts have said that evidence that supports a prima facie case is the "minimum quantum of evidence

csrprodcwi.motorolasolutions.com/StatusCheck.mvc/StatusCheck [https://perma.cc /A65F-EYV5]; Code Enforcement Process, SAN ANTONIO, https://www.sanantonio.gov/ces/Services [https://perma.cc/X5TY-KPFK]; Code Enforcement, LUBBOCK, https://ci.lubbock.tx.us/departments/code-enforcement/services [https:/ /perma.cc/WQ4A-PKAV] (showing the account creation page before submitting a complaint to Lubbock Code Enforcement Department).

172. Riston v. Doe \#1, 161 S.W.3d 525, 528-29 (Tex. App.-Houston [14th Dist.] 2004, pet. denied).

173. TEX. CIV. PraC. \& REM. CODE $\S 16.0045$ (b), (d) (allowing the filing of a John/Jane Doe suit to prevent the statute of limitations from running in personal injury cases involving sexual assault).

174. Complaint for Injunction \& Declaratory Relief at $12-13$, Khan v. City of Dallas, No. 3:15-CV-3254-D, 2016 WL 3910859, (N.D. Tex. Mar. 18, 2016).

175. Amended Complaint for Injunction \& Declaratory Relief at p. 4, Khan v. City of Dallas, No. 3:15-CV-3254-D, 2016 WL 3910859, (N.D. Tex. Mar. 18, 2016). Note that even if Texas allowed anonymous lawsuits, their purpose is to grant a plaintiff time to discover the identity of a defendant. Anonymous reporting leaves no record of a reporter's identity, therefore, the time extension an anonymous lawsuit provides would serve no purpose. See Riston, 161 S.W.3d at 530.

176. Tex. Civ. Prac. \& REM. Code $\S 27.005(\mathrm{~b})-(\mathrm{c})$.

177. In re Lipsky, 411 S.W.3d 530, 539 (Tex App.-Fort Worth 2013, pet. denied) (quoting TEX. CIV. PRAC. \& REM. CODE $§ 27.006(\mathrm{a})$ ). 
necessary to support a rational inference that the allegation of fact is true." 178 The plaintiff must provide evidence external to the pleadings. ${ }^{179}$ Although the TCPA allows the court to permit "specified and limited discovery relevant to [a] motion[,]"180 it restricts the admissible evidence at the pleading stage to the pleadings and supporting affidavits. ${ }^{181}$ Therefore, the exception has little applicability to helping a party overcome the procedural hurdle.

Texas courts have yet to apply the TCPA's evidentiary standard to anonymous code harassment, but a case from Austin, Texas demonstrates how a court might apply the evidentiary standard. In Neyland $v$. Thompson, a plaintiff successfully demonstrated a prima facie case for defamation against four defendants the plaintiff alleged created and distributed anonymous fliers to neighbors. ${ }^{182}$ The plaintiff provided clear and specific evidence that the defendants published the pamphlets using an eyewitness affidavit, one of the defendants distributed the fliers, and the other three defendants lack of a denial that they published the fliers. ${ }^{183}$ Without a denial from the other three defendants, the presence of evidence showing one of the defendants was in contact with defaming material was enough to move Thompson's claim from suspicion to a rational inference. ${ }^{184}$

Thompson's case shows that a court likely would have dismissed the Dallas pro se litigant's lawsuit against his neighbor-described above - as mere suspicion. The amended complaint stated: "In or about January of 2015, Plaintiff's disgruntled neighbor ... anonymously filed a false complaint with the City of Dallas." 185 The

178. Id. (quoting In re E.I. DuPont de Nemours \& Co., 136 S.W.3d 218, 233 (Tex. 2004)).

179. Gensetix, Inc. v. Baylor Coll. of Med., 616 S.W.3d 630, 639 (Tex. App.Houston [14th Dist.] 2020, no pet.).

180. TEX. CIV. PRAC. \& REM. CODE $\$ 27.006$ (b).

181. Amy Bresnen et al., Targeting the Texas Citizen Participation Act: The 2019 Texas Legislature's Amendments to a Most Consequential Law, 52 ST. MARY's L.J. 63, 120 (2020).

182. Neyland v. Thompson, No. 03-13-00643-CV, 2015 Tex. App. LEXIS 3337, at *9 (Tex. App.-Austin Apr. 7, 2015, no pet.) (mem. op.) (The first flier was signed anonymously, and the second was signed "Your concerned neighbors of Sunchase.").

183. Id. at *22 ("[They] do not dispute that they made the statements alleged to be defamatory.").

184. Id. at $* 22 \mathrm{n} .8$ (showing that the defendant the affidavit was against appealed separately from the other three defendants).

185. Am. Compl. for Inj. \& Declaratory Relief, at 4, Khan, No. 3:15-CV-3254-D, 2016 WL 3910859 (N.D. Tex. 2016). 
complaint further stated the neighbor "demanded that the blue tarp be replaced with a beige color tarp; as it did not please her taste of color" and that his "immediate family members and visiting friends heard [the neighbor] complaining." 186 The pro se litigant provided no supporting affidavits or evidence to support his three factual claims. ${ }^{187}$ Unlike the evidence in Thompson, the pro se litigant had no testimony to show that his neighbor made the actual anonymous complaint; he merely alleged that his neighbor disliked the color of the tarp he used. Without evidence connecting the neighbor and the anonymous complaint, the neighbor could deny submitting the complaint to code enforcement. The TCPA's evidentiary standard at the pleading stage, therefore, makes surviving motions to dismiss nearly insurmountable in situations where a code harasser is anonymous. ${ }^{188}$ Anonymous reporting, when combined with the TCPA, becomes a shield that code harassers can use to avoid liability.

\section{Molding Causes of Action}

After identifying a code harasser, a person must still have a viable cause of action to sue the harasser. Unlike criminal law that punishes false reports to police officers or harassment itself, no clear law provides a civil remedy for code harassment, so lawyers must cobble various claims from tort law. ${ }^{189}$

\section{Criminal Law}

Two failed criminal causes of action are false reporting and harassment. A false reporting claim offers Texas citizens no relief from code harassment because code enforcement officials are not police officers. ${ }^{190}$ A person is guilty of false reporting "if, with intent to deceive, [the person] knowingly makes a false statement that is material

186. Id.

187. Id. at $4-6$

188. Id. at 4-5. See Neyland, 2015 Tex. App. LEXIS 3337, at*22.

189. See generally Long Canyon Phase II \& III Homeowners Ass'n v. Cashion, 517 S.W.3d 212, 215 (Tex. App.-Austin 2017, no pet.) (suing for intentional infliction of emotional distress, harassment, and negligence); Cunningham v. Waymire, No. 14-17-00883-CV, 2019 Tex. App. LEXIS 9253, at*52 (Tex. App.-Houston [1st Dist.] Oct. 22, 2019, no pet.) (suing for "libel, intentional infliction of emotional distress, negligence, and conspiracy").

190. See Section I supra; Uzdavines, supra note 22, at 163. 
to a criminal investigation." 191 The person must make the statement "to a peace officer or federal special investigator conducting the investigation; . . . any employee of a law enforcement agency that is authorized by the agency to conduct the investigation and that actor knows is conducting the investigation; or a corrections officer or jailer."192

Nor does code harassment qualify as criminal harassment. Texas does not recognize civil harassment as an independent cause of action. ${ }^{193}$ Criminal harassment occurs when, "with intent to harass," a person:

(1) initiates communication and makes an obscene "comment, request, suggestion, or proposal";

(2) "threatens ... to inflict bodily injury ... or to commit a felony against [a] person," or the person's family, house members, or property;

(3) falsely reports that "another person has suffered death or serious bodily injury";

(4) repeatedly telephones another person "anonymously or in a manner reasonably likely to harass, annoy, alarm, abuse, torment, embarrass, or offend";

(5) makes and "intentionally fails to hang up or disengage" a telephone call;

(6) "knowingly permits a telephone under the person's control to be used" for harassment; or

(7) "sends repeated electronic communications ... reasonably likely to harass, annoy, alarm, abuse, torment, embarrass, or offend another.",194

Although many actions in the statute, such as sending electronic communications when making an online report or repeatedly making telephone calls, align with code harassment, the statute first requires intent from the harasser. ${ }^{195}$ For harassment, intent is result-oriented and occurs if the result of the conduct is the perpetrator's conscious objective. ${ }^{196}$ The code enforcement officer is an intermediary that

191. Tex. Penal Code $\S 37.08(a)$.

192. Id.

193. Van Gilder v. Van Gilder, No. 03-18-00258-CV, 2018 Tex. App. LEXIS 4804, at *9-10 (Tex. App.-Austin June 28, 2018, no pet.).

194. TeX. PenAl CODE $\S 42.07$ (a). An electronic communication is "a transfer of signs, signals, writing, images, sounds, data, or intelligence of any nature transmitted in whole or in part by wire, radio, electromagnetic, photoelectronic, or photo-optical systems." Id. at $\S 42.07(\mathrm{~b})(1)$.

195. Tex. Penal Code $\$ 42.07(\mathrm{a})$.

196. Blount v. State, 961 S.W.2d 282, 284 (Tex. App.-Houston [1st Dist.] 1997, writ ref'd). 
disrupts this direct action and shields the harasser from criminal liability because the harasser intends to make a report that causes a city employee to harass another person. ${ }^{197}$ The problems code harassment creates are, therefore, beyond the reach of current criminal law.

\section{Tort Law}

Tort law fails to provide an adequate solution for victims of code harassment. Lawyers often use a variety of torts, notably defamation, as causes of action against code harassment, but these causes of action fail to provide relief for future harms, and defamation has critical flaws in addressing code harassment. 198

In California, for example, a neighbor began a "campaign of harassment' that the appellate court opined was 'not hyperbole"" after a court-ordered mediation should have solved the dispute. ${ }^{199}$ For three years, the neighbor would operate a chainsaw outside of a victim's bedroom even "while it was raining, and even when it was snowing." 200 The victim was able to bring a court action for numerous torts, including "intentional infliction of emotional distress, nuisance, trespass, and/or invasion of privacy" and won " $\$ 90,000$ in compensatory damages . . . and $\$ 5,000$ in punitive damages," but still had to move to a different neighborhood because the neighbor continued to harass him. ${ }^{201}$ Although the victim was compensated for the past damages he suffered, tort law was powerless to prevent future harm, and the victim had to sell and leave his home.

In addition, courts are very unlikely to use injunctions to restrict people's access to state municipal resources. ${ }^{202}$ Like code harassment, vexatious litigation occurs when a person uses repeated litigation to

197. See id.

198. See Kinney v. Barnes, 443 S.W.3d 87, 101 (Tex. 2014) ("[An] injunction prohibiting future speech based on that adjudication impermissibly threatens to sweep protected speech into its prohibition and is an unconstitutional infringement."); Burbage v. Burbage, 447 S.W.3d 249, 263 (Tex. 2014) (citing Hancock v. Variyam, 400 S.W.3d 59, 71 (Tex. 2013)) ("A party may not recover exemplary damages unless the plaintiff establishes actual damages.").

199. Blomquist, supra note 13, at 405 (citing Clanton v. Carr, No. A104203, 2004 WL 2988609, at*1 (Cal. Ct. App. Dec. 28, 2004)).

200. Id. at 406 (citing Clanton, 2004 WL 2988609, at*1).

201. Id. (citing Clanton, 2004 WL 2988609 at *2-5).

202. See Chris Colby, Comment, There's a New Sheriff in Town: The Texas Vexatious Litigants Statute and Its Application to Frivolous and Harassing Litigation, 31 TEX. TECH. L. REV. 1291, 1297 (2000). 
harass another. ${ }^{203}$ Texas courts had injunctions as a tool to restrict vexatious litigation, but were hesitant to issue them and reserved them primarily for cases where a lawsuit was filed in multiple states. ${ }^{204}$ Texas courts' failure to use injunction to curb vexatious litigation caused the Texas Legislature to create a vexatious litigation statute to solve the problem. ${ }^{205}$

A common cause of action brought against code harassment is defamation, ${ }^{206}$ where a defendant negligently "publishe[s] a false statement" defaming the plaintiff and causing damages ${ }^{207}$ Defamation does not provide a solution to code harassment because code harassment can involve the publishment of true statements just as much as false statements and the "qualified privilege" defense threatens to raise the degree of fault to malice. ${ }^{208}$

Looking at the first failure, defamation claims protect peoples' reputations from false statements. ${ }^{209}$ Therefore, 100 complaints to code enforcement claiming a neighbor's grass is not to code, if true, are not actionable as defamation. Further, many ordinances are variable conditions that can be true when reported and false when investigated. ${ }^{210}$ For instance, imagine a harasser reports his neighbor when the neighbor's grass is an inch above code. A day after the report, the neighbor mows his lawn. When a code enforcement officer arrives to investigate, the grass is below an actionable length, but the neighbor's

203. Id. at 1292 .

204. Id. at 1297.

205. Id. at 1293.

206. See generally In re Lipsky, 411 S.W.3d 530, 537 (Tex App.-Fort Worth 2013, pet. denied) (suing for defamation, business disparagement, and civil conspiracy); Neyland v. Thompson, No. 03-13-00643-CV, 2015 Tex. App. LEXIS 3337, at *16 (Tex. App.-Austin Apr. 7, 2015, no pet.) (suing for libel per se and slander per se); Cunningham v. Waymire, 612 S.W.3d 52, 52 (Tex. App.-Houston [1st Dist.] 2019, no pet.) (suing for libel, intentional infliction of emotional distress, negligence, and conspiracy).

207. D Magazine Partners, L.P. v. Rosenthal, 529 S.W.3d 429, 434 (Tex. 2017); see also Shearson Lehman Hutton, Inc. v. Tucker, 806 S.W.2d 914, 922 (Tex. App.-Corpus Christi 1991, writ dism'd w.o.j.) ("Damages ... include compensation for injuries to reputation or character, mental anguish and other like wrongs incapable of money valuation.").

208. Dixon v. Sw. Bell Tel. Co., 607 S.W.2d 240, 242 (Tex. 1980).

209. Austin v. Inet Tech., Inc., 118 S.W.3d 491, 496 (Tex. App.-Dallas 2003, no pet.).

210. Jonathan Simmons, What to Do When Code Enforcement Becomes a Weapon?, PALM COAST OBSERVER (July 8, 2015), https://www.palmcoastobserver.com/article/what-do-when-code-enforcement-becomes-weapon [https://perma.cc/2QH8-XZK6]. 
report at the time was true. Even after 50 repetitions of this situation, the harasser's statements are not false, so the neighbor has no defamation cause of action. Yet, the neighbor is still subject to multiple visits from code enforcement officers attempting to do their jobs.

Defamation's second failure is the qualified privilege defense, applying where "one of several persons" with a common interest makes a statement "in a lawful manner and for a lawful purpose" with the reasonable belief that another person is entitled to know. ${ }^{211}$ A report to code enforcement invokes a qualified privilege defense because it reports potential matters of public concern to code enforcement officers. $^{212}$ In Honeycutt v. Forest Cove Property Owners' Association, a letter the defendants sent to four high school administrators about a plaintiff hosting high school parties on his property was conditionally privileged. ${ }^{213}$ Given that students' health and safety fell within the school official's duties and was of common interest to the community, the defendants reasonably believed that school officials and other neighbors were entitled to know about the plaintiff's conduct. ${ }^{214}$

The qualified privilege defense is likely to apply in defamation suits for the same reason. Like school officials whose duty is to protect the health and safety of students, code enforcement officers have a duty to protect the city from nuisances. ${ }^{215}$ Nuisances affect the community, so residents could reasonably believe that code enforcement officers, whose duty is to resolve such issues, are entitled to know about potential violations.

To overcome the privilege, the plaintiff must show that the harasser made the communication with actual malice, ${ }^{216}$ defined as "knowledge that it was false or with reckless disregard" that a "false defamatory statement was made with a high degree of awareness of [its] probable falsity."217 A plaintiff bringing a defamation claim

211. Dixon, 607 S.W.2d at 242.

212. See Honeycutt v. Forest Cove Prop. Owners' Ass'n, No. 14-98-01255-CV, 2001 Tex. App. LEXIS 3173, at *13-14 (Tex. App.-Houston [14th Dist.] May 17, 2001, no pet.).

213. Id. at $* 1-3, * 13$.

214. Id. at *13-14 ("School officials have a common interest in protecting the health and safety of their students on and off school grounds.").

215. See Law in Action, supra note 9, at 149; ZSAKO, supra note 31, at 6.

216. Dun \& Bradstreet, Inc. v. O'Neil, 456 S.W.2d 896, 899 (Tex. 1970); Ramos v. Henry C. Beck Co., 711 S.W.2d 331, 335 (Tex. App.-Dallas 1986, no writ) (plaintiff bears the burden of proving malice).

217. Foster v. Upchurch, 624 S.W.2d 564, 566 (Tex. 1981). 
against a code harasser, therefore, must show the harasser made each report with malice. Such a requirement ignores the nature of code harassment. The aggregated behavior rather than the individual complaints is the issue; it is the cumulation of all the complaints together rather than the details of each complaint that makes the conduct defamatory. ${ }^{218}$

Defamation is a square peg for a round hole. The tort can combat code harassment but, like Tort law in general, is incapable of addressing the problem on its own.

\section{CREATING A Solution}

Code harassment has no simple solution. Its three componentsthe TCPA, anonymous reporting, and no cause of action-operate as a single whole and solving one component without the others would only allow the problem to continue. The following Section outlines plausible reforms that would address code harassment's root causes and offer relief to victims.

\section{A. Rolling Back the Texas Citizens Participation Act}

To address code harassment, the Texas Legislature needs to reform the TCPA. As shown in Section IV of this Comment, code harassers invoke the TCPA using its broad language. ${ }^{219}$ The TCPA's broad reach was not exclusive to code harassment and had similar effects on nearly every type of litigation in the State. 220 "From April 2018 until April 2019, the Office of Court Administration reported 99,300 filed documents referenc[ing] the TCPA."221 Judges and attorneys requested the Texas Legislature amend the law, and, on September 1, 2019, the Legislature created a new version with only one vote

218. Gilbert Garcia, Beacon Hill Businesses Cry Code-Compliance Harassment, SAN ANTONIO EXPRESS-NEwS (Oct. 22, 2016), https:/www.expressnews.com/news /news_columnists/gilbert_garcia/article/Beacon-Hill-businesses-cry-code-compliance-10124431.php [https://perma.cc/DEW9-U4YV]; Betsy Calvert, Code Enforcement Starts With Neighbors, Ends With Government, Sun PORT CHARLOTTE (Apr. 12, 2019), https:/www.yoursun.com/charlotte/news/code-enforcement-starts-withneighbors-ends-with-government/article_217c3096-4a70-11e9-96ba-

ab64eac85ce6.html [https://perma.cc/CGB3-XDNF].

219. See Bresnen et al., supra note 181 , at 61 .

220. See id. at 62.

221. Id. 
against it. ${ }^{222}$ Two notable changes of the amended law have some applicability to code harassment but are unlikely to have any serious effect on the issue.

The first change narrowed the initial application of the TCPA. ${ }^{223}$ Before the amendment, the statute stated, "a court shall dismiss a legal action against the moving party if the moving party shows by a preponderance of the evidence that the legal action is based on, relates to, or is in response to a party's exercise of the right of free speech [or] right to petition." 224 Now, the statute states, "a court shall dismiss a legal action against the moving party if the moving party demonstrates that the legal action is based on or is in response to a party's exercise of the right of free speech [or] right to petition." 225

The two alterations to the statutory text were substituting the "preponderance of the evidence standard" with the word "demonstrates" and the removal of the phrase "relates to." The removal of the preponderance of the evidence standard prevents the court from having to apply a broad interpretation of the statute because the word "demonstrates" is not yet defined. ${ }^{226}$ Judges, therefore, will have a greater, but not unlimited, amount of discretion in determining whether to dismiss a case. ${ }^{227}$ The removal of the phrase "relates to" attempts to prohibit the broad application of the law to issues the legislature never intended the law to impact, such as matters in probate court. ${ }^{228}$ Now, courts may be able to sever extraneous cases the legislature never intended the statute to apply to through a narrow interpretation of the words "based on" and "in response to." 229

Unfortunately, the change is unlikely to impact code harassment because reports to code compliance are a direct petition to the government. ${ }^{230}$ Code harassers have been able to invoke the TCPA using the

222. Id. at 55 .

223. TEX. CIV. PRAC. \& REM. CODE $§ 27.003$ (a) (comparing the 2011 statute with the 2019 amendment).

224. $\$ 27.005(b)$.

225. $\$ 27.003(\mathrm{a})$.

226. Bresnen et al., supra note 181, at 116.

227. Id.

228. Id. at 61,113 .

229. See id.

230. See In re Lipsky, 411 S.W.3d 530, 539 (Tex App.-Fort Worth 2013, pet. denied); Cunningham v. Waymire, 612 S.W.3d 47, 67, 71 (Tex. App.-Houston [14th Dist.] 2019, no pet.). 
"based on" language, the strongest application of the statute. ${ }^{231}$ Although the amendment does not provide a direct solution to the statute's protection of harassing behavior, it does illustrate a state-wide acknowledgement that the law has been overly broad and may be a sign of future changes.

The second change impacts the admissible evidence a court can consider in a TCPA motion to dismiss. ${ }^{232}$ Under the old law, a court could only consider pleadings and supporting affidavits. ${ }^{233}$ After the amendment, a court can consider the "types of evidence allowed under the summary-judgement rule: deposition transcripts, interrogatory answers, admissions, stipulations of the parties, and authenticated or certified public records." ${ }^{234}$ The inclusion of new types of evidence promises to add more weight to a judge's decision to allow additional discovery under a motion to dismiss. ${ }^{235}$ Although such a change promises to have some positive effect on defeating TCPA motions, the amendment is unlikely to impact code harassment where evidence is nearly impossible to gather. ${ }^{236}$

Despite the amendments offering little solution to code harassment, the additional exceptions added to the law offer an avenue for future reform. The original law had four exemptions that shielded four types of cases from the TCPA. ${ }^{237}$ The amendment added 15 new exemptions, including cases involving evictions, common law fraud claims, and survivors of sexual assault. ${ }^{238}$ Including code harassment among these exemptions would be a method of removing TCPA protections from code harassers without relying on judicial interpretations or complicated statutory construction. For instance, an exemption could apply against defamation claims where the defendant has submitted 50 or more complaints to a municipal code compliance department. Although the TCPA has undergone extensive reform, its broad overreach and harsh evidentiary requirements promise to protect code harassment until the legislature addresses the problem with further reforms.

231. See Lipsky, 411 S.W.3d at 543; Cunningham, 612 S.W.3d at 67, 71.

232. Bresnen et al., supra note 181, at 115-20.

233. Id. at 114 .

234. Id. at 117.

235. See id.

236. See generally supra Section IV(b).

237. Bresnen et al., supra note 181, at 100.

238. Id. at 101-05. 


\section{B. Transitioning Anonymous Reporting to Confidential Reporting}

Cities need to transition from anonymous to confidential reporting systems. Proponents of anonymous reporting argue that it protects reporters from retaliation. ${ }^{239}$ Without anonymous reporting, people would be unwilling and unable to make use of code compliance ${ }^{240}$ for fear of retaliation and harm from neighbors. ${ }^{241}$ However, adopting a confidential reporting system, where code enforcement documents a reporter's identity but protects it from the public, is a solution that retains the protections advocates of the anonymous system endorse while addressing the problem of code harassment.

Municipalities should require complainants to provide their identity to authorities. In exchange, their identities could be confidential and exempt from disclosure under the Texas Public Information Act, which requires governmental authorities to disclose information to citizens on request. ${ }^{242}$ The legislature could add an exception to the Texas Public Information, limiting a retaliatory neighbor's access to a complainant's identity. ${ }^{243}$ In this way, the information would be available only during discovery in litigation involving code harassment ${ }^{244}$ but hidden from neighbors seeking to punish a neighbor for filing a single report.

Nor would the switch from anonymous to confidential reporting deter people from reporting code violations. For example, Lubbock functions without anonymous or confidential reporting. ${ }^{245}$ Lubbock citizens must create and log into an account to access the online complaint form. ${ }^{246}$ This means Lubbock citizens cannot anonymously

239. Jonathan Simmons, What to Do When Code Enforcement Becomes a Weapon?, PALM COAST OBSERVER (July 8, 2015), https://www.palmcoastobserver.com/article/what-do-when-code-enforcement-becomes-weapon [https://perma.cc/2QH8-XZK6].

240. Id.

241. Lindsay Whitehurst, Man Says He Killed City Worker Over Yard Rule 'Harassment,' ASSOCIATED PRESS (Aug. 10, 2018), https://apnews.com/article /bde88b80d72147859f5d6a7a4d621ef2 [https://perma.cc/9CET-46TX].

242. TEX GOV'T CODE $§ 552.001$.

243. See § 552.1175(a)(8) (protecting police officers' identities); § 552.002(18) (protecting government settlement agreements).

244. §552.0055 (discovery requests are not a "request for information").

245. Code Enforcement, LuBBOCK, https://ci.lubbock.tx.us/departments/code-enforcement/services [https://perma.cc/WQ4A-PKAV]; Sign in, SEECLICKFIX, https:/ /seeclickfix.com/oauth/login [https://perma.cc/4QYX-W8MF].

246. Code Enforcement, LUBBOCK, https://ci.lubbock.tx.us/departments/code-enforcement/services [https://perma.cc/WQ4A-PKAV]; Sign in, SEECLICKFIX, https:/ 
report. However, many citizens continue to regularly contact code enforcement for problems such as high weeds and junked vehicles. ${ }^{247}$ The lack of an anonymous complaint system has not completely deterred Lubbock citizens' use of code compliance. ${ }^{248}$ Therefore, requiring complainants to provide their identity in exchange for making the information confidential to the public is an equitable solution that balances the complainant's privacy with the need to identify harassing reporters.

\section{Creating a Vexatious Reporting Law}

Available causes of action fail to directly address code harassment. Without a clear cause of action, people cannot take the knowledge that a specific person is harassing them and legally force them to stop. Fortunately, Texas's vexatious litigant law offers a clear model for creating a vexatious reporter law. ${ }^{249}$

A court may find a plaintiff a vexatious litigant if a defendant shows that there is not a reasonable probability the plaintiff will succeed and the plaintiff:

(1) "commence[s], prosecute[s], or maintain[s] at least five litigations" pro se that were "determined adverse," left pending for two years, or dismissed as frivolous;

(2) attempts "to relitigate, pro se," a previous cause of action "arising out of the same controversy"; or

(3) is already "a vexatious litigant in a case arising out of the same controversy." 250

A court may prohibit a vexatious litigant from filing new litigation ${ }^{251}$ or require a security to pay the defendant's attorney's fees if the court later dismisses the litigation. ${ }^{252}$

There are four noteworthy features of the vexatious litigant law allowing it to function:

/seeclickfix.com/oauth/login [https://perma.cc/4QYX-W8MF] (showing the account creation page before submitting a complaint to Lubbock Code Enforcement Department).

247. City of Lubbock Monthly Code Cases, ARCGIS InSIGHTS, https://insights.arcgis.com/index.html\#/view/675d4ea644c1494bb2b871e41393e8e2 (last visited Oct. 15, 2021) (Filtering the reported code cases by month shows Lubbock citizens made 1,814 reports to Lubbock Code Compliance during January 2021).

248. $I d$.

249. See supra Section IV(c)(2).

250. TeX. Civ. Prac. \& REM. CODE $§ 11.054(1)-(3)$.

251. § 11.101(a).

252. $\S \S 11.055(\mathrm{a}),(\mathrm{c}), 11.057$. 
(1) there is a bright-line rule for the number of suits (five), during a seven-year period; 253

(2) the law still allows for meritorious claims: 254

(3) every judge may block litigation up front, ${ }^{255}$ and

(4) a vexatious litigant with a meritorious claim must post security. ${ }^{256}$

The first feature, that there is a bright-line rule for the number of suits, limits the court's ability to label people as vexatious litigants because the person must meet an objective standard of unreasonableness. ${ }^{257}$ The second feature, that the law still allows for meritorious claims, allows the law to survive three constitutional challenges: First Amendment deprivation, vagueness, and overbreadth. ${ }^{258}$ The third feature, every judge may block litigation up front, allows judges to prevent the harassment before it begins, a process made simple with a public list of vexatious litigants maintained and updated online. ${ }^{259}$ The fourth feature, a vexatious litigant with a meritorious claim must post security, imposes a steep financial penalty for each filed litigation that many vexatious litigants cannot afford with their persistent behavior. $^{260}$

Using the four primary features of the vexatious litigant statute as a guide, a vexatious reporter statute would first need to establish a bright-line rule triggering the statute. ${ }^{261} \mathrm{~A}$ rule with a minimum threshold would prevent code enforcement departments from using the statute to silence complaints. In drafting this requirement, lawmakers would need to consult with code compliance officers to determine what number of complaints are considered unacceptable harassment, whether all or some of the reports need to be false, and whether the

253. See Colby, supra note 202, at 1323 .

254. See id. at 1343-44.

255. See id. at 1339-40.

256. See id. at 1331.

257. See Barker v. Hutt, 2012 Tex. App. LEXIS 5565, at*9-10 (Tex. App.Eastland July 12, 2012, no pet.).

258. See Sparkman v. Microsoft Corp., No. 12-13-00175-CV, 2015 Tex. App. LEXIS 2510, at *8-15 (Tex. App.-Tyler Mar. 18, 2015, pet. denied).

259. See Vexatious Litigants, TEX. JUD. BRANCH, https://www.txcourts.gov/judicial-data/vexatious-litigants/ [https://perma.cc/X8TX-LPL7].

260. See Sparkman, 2015 Tex. App. LEXIS 2510, at*8-15 (confirming the dismissal of a case because a registered vexatious litigant failed to furnish a $\$ 7,500$ security); Colby, supra note 202, at 1304.

261. See Tex. Civ. Prac. \& REM. Code $§ 11.054(1)-(2)$; Colby, supra note 202, at 1323. 
law should focus on complaints made against one person or complaints made by a specific person.

Next, a vexatious reporter statute would need to hamper, but not outright prevent, complaints to code enforcement from vexatious reporters. ${ }^{262}$ This protects free speech rights and ensures that a court will not strike the law on constitutional grounds. ${ }^{263}$

Third, a vexatious reporter statute would need to require code enforcement departments to review reports for plausibility from known vexatious reporters. ${ }^{264}$ This would require code enforcement agencies to review vexatious reporter's complaints before making them public or investigating them. A code enforcement officer would have to read or discuss the claim, assess it, and take responsibility for accepting it. This process, like a judge reviewing the merits of a litigation case, establishes a roadblock that prevents officers from interacting with the intended victim.

Lastly, a vexatious reporter statute would need to require vexatious reporters to pay money to make complaints. ${ }^{265}$ This imposes financial penalties onto a system that is otherwise free. ${ }^{266}$ A vexatious reporter who would report every person in a neighborhood will have to assess whether she can afford such behavior. Adding money into the system curbs harassing behavior while still allowing the person the opportunity to make her neighborhood a better place.

More importantly, creating a cause of action would promote judicial efficiency. Currently, victims of code harassment mold and argue claims, such as defamation, to enter court. ${ }^{267}$ Attorneys add claims, like negligence and even private nuisance, because the law is unclear on what causes of action address this issue. ${ }^{268}$ Judges, therefore, devote significant resources to researching, analogizing, and trying such

262. See Tex. Civ. Prac. \& Rem. Code $§ 11.101(a)$; Colby, supra note 202, at $1343-44$.

263. See Sparkman, 2015 Tex. App. LEXIS 2510, at*8-15.

264. See TeX. Civ. Prac. \& ReM. Code $\S 11.101(a)$; Colby, supra note 202, at $1339-40$.

265. Tex. Civ. Prac. \& Rem. Code $\S \S 11.055(a)$, (c), 11.057; Colby, supra note 202 , at 1331 .

266. Request a City Service, FORT WORTH, https://fortworth-csrprodcwi.motorolasolutions.com/servicerequest.mvc/srintake [https://perma.cc/LFJ38AAX] (charging no fee for the submission of a complaint).

267. See supra Section IV(c)(2).

268. See id. 
cases. $^{269}$ A clear cause of action with well-established limits and boundaries would allow judges to dismiss claims filed under improper causes of action while addressing the issue when properly presented. Ultimately, creating a cause of action for code enforcement not only allows victims to gain relief, but also eases the strain such cases place on the legal system.

\section{CONCLUSION}

Cities have focused their efforts on protecting reporters from vengeful neighbors but, in the process, created a system that enables some reporters to harass their neighbors. This Comment has shown how these protections have extended too far. ${ }^{270}$ In Texas, the TCPA, anonymous reporting, and the lack of a specific cause of action are three issues that enable code harassment. ${ }^{271}$ Creating a solution to the problem requires a simultaneous three-pronged approach that aims to retain the positive parts of these three systems while minimizing their negative aspects. ${ }^{272}$ As a balanced solution, this Comment advocates for the Texas Legislature to add code compliance complaints as an exception to the TCPA, cities to transition from anonymous to confidential reporting systems, and the Texas Legislature to create a vexatious reporter statute. ${ }^{273}$

Although code harassment has historically been a local problem confined to neighborhood disputes, ${ }^{274}$ the internet has expanded the problem's reach. ${ }^{275}$ As the closure of DIY spaces shows, people and groups will be able to use anonymous reporting to retaliate against political opponents or attack marginalized groups. ${ }^{276}$ Without creating a solution that addresses the problem today, code harassment could expand into a national tool of harassment.

Ultimately, this Comment argues that injecting additional oversight measures into the code enforcement process is the best way to

269. See id.

270. See supra Section IV.

271. Id.

272. See supra Section V.

273. Id.

274. See generally Bob LaMendola, Vengeful Neighbors Trigger 'Code Terrorism, ' S. FLA. Sun SENTINEL (Apr. 30, 1989), https://www.sun-sentinel.com/news/fl -xpm-1989-04-30-8901220735-story.html [https://perma.cc/CKQ9-QYX4].

275. See generally DIY, supra note 15.

276. Id. 
fight code harassment. Hopefully, such oversight can catch the instances when code enforcement departments fail and prevent situations where a neighbor with a tape measure forces another person to abandon her home. ${ }^{277}$

277. See Gilbert Garcia, Beacon Hill Businesses Cry Code-Compliance Harassment, SAN ANTONIO EXPRESS-NEwS (Oct. 22, 2016), https://www.expressnews.com /news/news_columnists/gilbert_garcia/article/Beacon-Hill-businesses-cry-codecompliance-10124431.php [https://perma.cc/DEW9-U4YV]. 